\title{
REKLAMLARDA ÜNLÜ KULLANIMI: OPPO VE SILA REKLAM KAMPANYASI ÖRNEĞİ
}

Mihalis KUYUCU ${ }^{1}$

Özet

Ünlüler her zaman insanların ilgisini çekmiştir. Yaşam tarzlarını model olarak alan insanlar, özellikle gençler, ünlüleri her zaman odak noktalarına almışlardır. Nasıl giyindikleri, özel hayatlarında neler yaptıkları, kullandıkları eşyalara kadar pek çok unsur ünlüleri takip edenler tarafından dikkate alınır. $\mathrm{Bu}$ sosyolojik durum reklam endüstrisini ürünleri reklam kampanyalarında kullanmaya yönlendirmiş̧tir. Özellikle neo-liberal ekonominin yaygınlaştığı, iletişim araçların çeşitliliğinin arttığı ve bunun tüketime yansıdığı seksenli yıllarda reklam endüstrisi de büyük bir atılım yaşamıştır. Reklam endüstrisinin büyümesi bu alanda rekabeti de arttırmış ve reklam ajansları temsil ettikleri ürün ve hizmetlerin reklamlarını yaparken ünlü kullanımına daha fazla önem vermeye başlamıştır. Yapılan uygulamalarda elde edilen sonuçların da müspet olması markaları reklam kampanyalarında ünlüleri kullanılmasına itmiştir. Ünlülerin popülerliğinden faydalanılan bu reklamlarda ünlülere çok yüksek bedeller ödenmekte ve marka ile markanın ürün ve hizmeti ile o ünlü arasında bir bağ yaratılmaktadır. Yaratılan bu bağın tüketici ile de ortak bir paydada buluşması ve bunun tüketim eylemine dönüşmesi hedeflenmektedir. Bu çalışmada ilk marka ve ürün kampanyasını 2019 y1lının son çeyreğinde ünlü şarkıcı Sıla ile gerçekleştiren ve "reklamda ünlü kullanma" stratejisini uygulayan OPPO'nun reklam kampanyasının çıktıları hakkında betimsel bir araştırma yapılmıştır. 316 üniversite öğrencisine anket yolu ile uygulanan araştırmaya katılanların tamamına yakın bir bölümü reklamlarda ünlü kullanımının avantaj getiren bir strateji olduğunu belirtmiştir. Oppo reklamını başarılı bulanların oranı yüzde 48,3 iken, reklamda ünlü olarak Sıla'nın seçilmesinde ürün hedef kitle ile uyumlu bir karar olduğunu düşünenler yüzde 37 oranında olmuştur. Araştırmada reklam ile ünlü kullanımının etkileri, ünlünün markanın hedef kitlesine uyumu, reklamın senaryosu ve konusuna yönelik düşünceler ve reklamda ünlü kullanımının ürün tercihine olan etkilerine OPPO reklamı örneğinden hareket edilerek değerlendirilmiştir.

Anahtar Kelimeler: Reklam, reklamda ünlü kullanımı, sıla, oppo,

\section{CELEBRITY USE IN ADVERTISING: CASE OF OPPO AND SILA ADVERTISING CAMPAIGN}

\begin{abstract}
Celebrities have always attracted people's attention. People who take their lifestyles as models, especially young people, have always focused on celebrities. Many lifestyles, such as how they dress, what they do in their private lives, and the items they use, are taken into consideration by those who follow celebrities. This sociological situation has led the advertising industry to use products in advertising campaigns. In the eighties, when the neo-liberal economy became widespread, the variety of communication tools increased, and this was reflected in consumption
\end{abstract}

\footnotetext{
${ }^{1}$ Doç. Dr., Alanya HEP Üniversitesi Tasarım Bölümü, e-posta: michaelkuyucu@ gmail.com, ORCID: 0000-0002-1931-6844
} 
which lead the advertising industry also to be experienced with a great breakthrough. The growth of the advertising industry has also increased the competition in this area and advertising agencies have succeeded in giving more importance to their celebrity use when advertising the products and services they represent. The fact that the results obtained in the applications are also positive has pushed the brands to use celebrities in advertising campaigns. In these advertisements that take advantage of the popularity of celebrities, celebrities are paid very high prices and a link is created between the brand and the brand's product and service. It is aimed that this created bond will meet with the consumer on a common ground and this will result in an act of consumption. In this study, a descriptive research was conducted on the outputs of OPPO's advertising campaign, which carried out its first brand and product campaign with the famous singer S1la in the last quarter of 2019 and implemented the strategy of "using celebrity in advertising". Almost all of the participants in the survey, which was applied to 316 university students through a questionnaire, stated that the use of celebrity in advertisements is an advantageous strategy. While the rate of those who found the Oppo advertisement successful was 48.3 percent, the rate of those who thought that the product was a decision compatible with the target audience in the selection of S1la as celebrity in the advertisement was 37 percent. In the research, the effects of the use of celebrities in advertising, the compatibility of the celebrity with the target audience of the brand, the ideas about the scenario and the subject of the advertisement, and the effects of the use of the celebrity in the advertisement on the product preference were evaluated by using the example of OPPO advertisement.

Keywords: Advertising, celebrity use in ads, s1la, oppo

\section{GíRiș}

Liberal ekonomik modellerin yaygınlaşmasının bir sonucu olarak reklamcılık, kitle iletişiminin gelişim seyrine bağlı olarak farklı dönemler yaşamıştır. İnsanlığın evrimi ve teknolojik gelişmelere bağlı olarak reklamcılığın tarihi, Antik Mısır döneminde köle satışlarını teşvik etmek için papirüslerle duyuru yapılmasına dek gitmektedir.

Bugün dünyada basılı medya, televizyon, radyo, dijital medya gibi birçok farklı kitle iletişim aracı bulunmaktadır. Reklam ajansları ürünleri tanıtmak ve duyurmak için bu medya araçlarını kullanırlar. Bu medya araçları sayesinde çok sayıda insana ulaşmak kolaylaşmaktadır.

Reklamcilık, bir hizmeti, ürünü veya fikri teşvik etmenin bir sonucu olarak yeni davranışları şekillendirmeyi, hedef tüketicilerin tutumlarını değiştirmeyi veya güçlendirmeyi amaçlamaktadır. Reklamlar ne satılacağına ve ne alınacağına karar verebilmek için hem reklam verenler hem de tüketiciler için faydalar sunmaktadır. Bununla birlikte farkında olsak da olmasak da reklamlar hayatımızı yönlendirmektedir. Genel olarak reklamlar kararlarımızı, satın alma davranışımızı, satın alma sürecimizi ve satın alma şeklimizi etkiler. Bu nedenle çok farklı reklam stratejileri ortaya çıkmıştır. Bunlar arasında en sık uygulananlardan biri de reklamlarda ünlü kullanımıdır.

Dünyanın her yerinde ünlüler, yarattıkları olumlu etki ve imaj sayesinde tüketiciler tarafından takip edilmektedir. Ünlüler tarafından tanıtılan veya tercih edilen firma-ürün-markalar 
ünlülerin özel hayatı ile özdeşleştirilmektedir. Ünlülerin çekiciliği, uzmanlığı ve güvenilirliği tüketicilerin o ürüne bakış açısını olumlu ya da olumsuz yönde değiştirebilmektedir. Reklamlarda sıklıkla tercih edilen ünlü kullanma stratejisi, bu çalışmanın temel inceleme alanını oluşturmaktadır.

\section{Reklam ve Reklameılık Tanım ve Kapsamları}

Reklam, gündelik hayatın pek çok alanında karşılaşılan, tüketim kültürü ile ilgili zihinsel bir olgudur. Bu kapsamda reklamcılık serbest piyasa ekonomisi içinde üretici ve tüketici arasındaki arz-talep ilişkisinden doğan, bu ilişkinin geniş bir alana yayılmasına hizmet eden dinamik bir süreçtir.

Günümüzde reklam, pazarlama karmasının en önemli parçası durumundadır. İşletmeler ürünlerini pazarlamak ve potansiyel müşterilere ulaşmak için reklamlara başvurmaktadır. Müşterileri ve ürünleri birbirine bağlayan reklamlar bir iletişim aracı olarak da düşünülebilir.

Reklam, pazardaki yeni ürünler, hizmetler veya fikirler hakkındaki araştırmalar gibi etkinliklerin birleşimidir. Bu ürün, hizmet veya fikirler için alıcıların profilleri hakkında yapılan araştırmalar, reklamın amacının, maliyetlerinin, bütçelerinin ve ortamının ve tüm hazırlık aşamalarının belirlenmesini kapsamaktadır. Arens (1996: 6) reklam tanımlarının oldukça fazla olduğunu belirtmiştir. Genel bir açıklama ile reklam bir iletişim süreci, bir pazarlama iletişim süreci, bir ekonomik ve sosyal süreç, bir halkla ilişkiler süreci veya bir bilgi ve ikna süreci olarak da açıklanabilmektedir.

Ünsal (1984: 12)'a göre reklam “bir işin, malın veya bir hizmetin para karşıllı̆̆ında, genel yayın araçlarında tarif edilerek geniş halk kitlelerine duyurulmasıdır."

Tüketicilerin bakış açısına göre reklam, pazarda kendi ihtiyaçlarına cevap veren binlerce ürün arasından kendi yararına en uygun ve rasyonel seçimi yapmasına yarayan bir araçtır (Topsümer ve Elden, 1997: 14).

Ekonomik sistemde bir tür kaldıraç görevi gören reklamlar, sosyal sistemde ise belirli kesimlere sadece ürün veya marka değil bir yaşam tarzı, bir bakış açısı yükleme gücüne de sahiptir. Bu bakış açısıyla reklam bir şeyin varlığını duyurmaktan çok ikna etme çabası ile hareket eden, bir talep yaratma sanatıdır (Tosun, 2014: 509).

Yukarıda belirtilen tüm tanımlarda açıkça görüldüğü gibi, reklamda iletişim süreci olmak, ikna edici olmak, bilgilendirici olmak gibi bazı önemli hususlar vardır. Bu çalışmada reklam, genellikle seçilen pazarın bilgilendirilmesi ve tüketicilerin ikna edilmesi için belirlenen bir sponsor tarafindan ödenen fikirlerin, ürünlerin ve hizmetlerin kişisel olmayan iletişiminin kontrollü bir şekli olarak kabul edilecektir.

Reklam, tüketicilerin marka hakkında bilgilendirilmesini ve markanın ürün ve hizmetlerini tanıtmasını sağlamak için stratejik olarak planlanmış bir iletişim sürecidir. Reklamcılığın bir diğer önemli görevi de tüketicileri satın almaya ikna etmektir. İkna edici iletişim ve tüketici davranış1 gibi araştırma konuları, tüketicileri satın alma konusunda yönlendirmek amacıyla reklamcılık için giderek daha önemli hale gelmektedir (İplikçi 2015: 51). 
Reklamda bir marka veya fikir için hedef kitleyi genelde harekete geçirme yönünde belirli etki sürelerinden geçirme amaçlanmaktadır. Gereksinim oluşturma, tanıma ve hatırlatma yolu ile farkındalık sağlama, bilgi verme, tutum oluşturma, satın alma niyet oluşturma, satın almayı sağlama, sadakat yaratma ve satış sonrası tatmin oluşumunu destekleme reklam mesajlarının hedef kitlede oluşmasını amaçlayan etki süreçlerinden bazılarıdır (Tosun, 2014: 508).

\section{Reklamın Amaçları ve İşlevleri}

Reklam esas itibariyle hedef aldığg tüketici kitlesi üzerinde belirli bir etki yaratmak ve bu kitlenin düşünme ve alışkanlıklarını etkilemek yoluyla satın almaya yönlendirmek ve işletmenin karlılığını arttırma amacını taşır (Topsümer ve Elden, 1997: 21).

Reklam bir kitle iletişim yöntemidir. Kaynak veya reklamveren, basıll, görsel ve işitsel medya yanı sıra internet gibi elektronik kitle iletişim araçları aracılığıyla alıcılara ürünler, hizmetler veya fikirler hakkında mesaj gönderir. Temel olarak, reklamcılığın en önde gelen işlevinin ekonomik olduğu söylenebilir.

Reklamın iletişim amacı bilindiği gibi tarafsız bir iletişim değil, tam tersine üretici tarafından bilinçli olarak yönlendirilmiş, biçimlendirilmiş bir iletişimdir. Reklamdan beklenen gerçekleştirilmesi istenen başlıca amaç, üreticinin pazara sunduğu ürünün satılmasını sağlamak ve satışı devam eden bir ürünün pazar tarafından var olan talebini artırmaktır (Topsümer ve Elden, 1997: 23).

Kullanıcılar, bir ürünün nereden satın alınabileceğini ve fiyatını reklamlardan öğrenir. Böylece farklı alternatifleri değerlendirme fırsatı bulur. Reklamcılık, reklamverenler için iki temel işleve sahiptir: bilgilendirme ve ikna etme. Önce tüketicileri neyin mevcut olduğu ve ne için olduğu konusunda bilgilendirir. Daha sonra, ihtiyaç duydukları konusunda onları ikna eder. Tüketiciler için ise reklamcılığın dört ana işlevi vardır:

- Reklam, bilginin kaynağıdır. Tüketiciler yeni ürünler ve hizmetler hakkında bilgi edinmektedir.

-Daha önce de belirtildiği gibi, satın alma karar sürecini kısaltır.

- Reklamı yapılan ürünün iyi kalitede olduğu fikrini verebilir.

Reklamın üç önemli işlevi vardır. Bunlar bilgi, ikna ve hatırlatma işlevidir. Belirli bir özelliğe sahip ürünlerin reklamları bilgilendirici olmalıdır. Reklamlar, tüketicileri ikna ederek ürün veya hizmet satın almaya teşvik eder.

Tüketiciler satın alma davranışlarında belirli bir sırayla hareket ederler, bu alışkanlıkları değiştirmek için harici bir etki uygulamak gerekebilir. Reklam, tüketiciye fiyat, renk, ürünün özellikleri, yeni bir ürünün piyasaya sürüldügü ve mevcut olduğu yerler gibi bilgiler sağlar. Bilgi ise tüketicinin güvenini sağlamak için reklamın en önemli işlevi olarak karşımıza çıkar.

Günümüzün rekabetçi ortamında, piyasada birbirine benzeyen birçok ürün ve hizmet bulunmaktadır. $\mathrm{Bu}$ yoğunluk içinde tüketicinin seçim yapması zordur. $\mathrm{Bu}$ bağlamda reklam, tüketicileri reklam yoluyla bilgilendirmek ve motive etmek açısından giderek daha önemli hale gelmektedir. 
Tanıtım yöntemleri arasında önemli bir rol oynayan reklamcılık, ürünün ve markanın ticari başarısında önemli bir paya sahiptir. Özellikle, birçok benzer ürünün rekabet ettiği işgücü piyasasında reklamın önemi daha da fazladır. $\mathrm{Bu}$ nedenle, şirketlerin ürünlerinin farkını vurgulamaları ve tüketiciyi etkileyen reklam stratejileri geliştirmeleri gerekmektedir.

Günümüzde reklamc1lı, dünya ekonomisinden büyük pay alan önemli bir sektör durumundadır. Doğrudan ve dolaylı olarak iş yaratır, yaşam tarzları yaratır, markalar ve tüketiciler arasında ilişkiler kurar (İdris vd, 2009: 67).

Rekabetin yoğun olduğu bir pazarda, şirketler reklamlarla pazarda daha iyi bir yer edinmeye ve rakiplerine göre rekabet avantajı elde etmeye çalışırlar. Şirketlerin pazar payı kapasitelerini artırmak için tanıtım faaliyeti olarak kullandıkları azami işletme sayısı azalır, birim maliyetler azaltılır ve üreticiler için reklam avantajlı bir hale gelir.

Genel ekonomi açısından bakıldığında, reklamın talep yarattığı ve mevcut talebi artırarak üretimde artışa neden olduğu için bir avantaj olarak kabul edilir. Sonuç olarak, birim maliyetlerin düşmesine ve rekabet ortamının canlandırılmasına, fiyat kesintilerine yol açmaya, yenilik sayısını artırmaya, ürün çeşitliliğini artırmaya ve kaliteyi artırmaya katkıda bulunmaktadır. Bu bağlamda, rekabetin gereği olarak reklamların ortaya çıktığını ve şirketleri ürünlerini ve yenilikçi fikirlerini geliştirmeye zorladığını söylemek mümkündür. Reklamlar sayesinde üreticilerin ürünlerine olan talep artmakta ve bunun sonucunda ekonomi yeniden canlanmaktadır.

\section{Reklamcılığın Gelişim Süreçleri}

3000 yıllık bir mirasa dayanan reklamcılık, ticaretin başlangıcı kadar eskidir. Reklamcılıkta kullanılan ilk araç insan sesiydi. Sözlü reklamcılığın ilk örneği, satıcıların ürünlerini anlatmak için bağırdığı eski Mısır'da ortaya çıkmıştır. E n eski yazılı reklam örnekleri, satıcıların ürünlerinin satışta olduğunu metinle göstererek müşterileri çekmeye çalıştığ Antik Yunan ve Roma'da bulunmuştur (Karaçor, 2007: 123).

Ortaçağ'da zanaatkârlar ürettikleri ürünlerin kendilerine ait olduğunu ve ürünlerin ne olduğunu belirtmek amacıyla, üzerlerine bireysel markalarını ve işaretlerini yerleştirmişlerdir. Zanaatkârların ürünlerinin üzerinde bulunan günümüz marka anlayışını hatırlatan bu işaretler, Babil kalıntılarında bulunmuştur (Okay, 2009: 8).

Okuma yazma oranının çok az olduğu bu dönemde satılacak ürün ya da hizmetlerin özelliklerini ifade etmek için çeşitli resimler kullanılmıştır. Örneğin, bir fırını tanımlamak için ekmek ve bir ayakkabıyı tanımlamak için ayakkabı resmedilmiştir. Eski Roma'da, Yunan'da ve Mısır'da yapılan arkeolojik çalışmalarda ise, duvarlara ve taş tabletlere kazılmış çok sayıda reklam unsuruna rastlanmıştır. Bu tabletler günümüzün ilk reklam panolarına ait örnekler olarak değerlendirilmektedir (Okay, 2009: 8-9).

Eski Roma'da dükkânların önlerinde bulunan gezici satıcılar dükkân sahiplerinin sattıkları ürünlere alıcı bulmak amacıyla bağırırlardı. Bu durum Ortaçağ'ın ilk ilkel ticari reklam ilanları denilebilecek bir niteliktedir.

Bugün anladığımız şekli ile reklamın biçimlendirilme aşaması, 1440'ta Almanya'da J. Gutenberg'in matbaayı icadı ile başlamıştır. Değişebilir metal harf sistemiyle birlikte gelişen 
basın, reklam tarihindeki en önemli kilometre taşlarından biri olmuştur. Basılı reklamlar, matbaanın icadından sonra bir araç olarak işaretlere ve ticari markalara katılmıştır.

İngiltere'de ve belki de dünyada ilk basılı ilan, 1472'de basılmış bir dua kitabını açıklayan bir el ilanı olmuştur. Ancak günümüzde kabul edilen şekli ile bu bir gazete ilanı olarak kabul edilmemektedir (Barres, 2006: 6).

Bir sonraki adım gazetenin gelişimi olmuştur. Gazete sayesinde yazılı reklamlar daha popüler hale gelmiştir. Bilinen en eski gazete reklamı, 1591'de Almanya'da yayınlanan bir kitabın reklamı olmuştur. Gazete reklamları kısa sürede çoğu gazetede görünmeye başlamıştır.

Reklamcılık açısından tarihi dönemlerden biri de kuşkusuz Sanayi Devrimi'dir. 1700'lerin ortalarında İngiltere'de başlayan Sanayi Devrimi 1800'lerin başında dünyanın birçok yerine ulaşmış ve bu süreç ile birlikte üreticiler aynı kalitede çok sayıda mal üretmeye başlamıştır. Yüksek miktarda mal üretmek için üreticilerin kitle tüketimine ihtiyacı vardı ve kitle pazarlarına mallar ve ürünler hakkında bilgi verme imkânı vardı. Bu sayede reklamcılığın önemi anlaşılmış ve bu durum pazarların genişletilmesine yardımcı olmuştur. Dolayısıyla ekonomik alanda reklam, sanayileşme hareketi ile birlikte gelişmeye başlamıştır. $\mathrm{Bu}$ alanda reklamı ortaya çıkaran makineleşme hareketi ve bunun doğal sonucu olarak da kitle üretimidir. Ancak bu dönemde yapılan reklamlar gerek teknik açıdan gerekse mesaj ve stratejik çalı̧̧malar yönünden detaylı ve profesyonel hazırlanmadıkları için yeterince etkili değildir (Topsümer ve Elden, 1997: 19).

İngiltere 1712 y1lında basılı reklamlardan vergi alan ilk ülke olmuştur. Bunu diğer devletler izlemesine rağmen, basında yayınlanan reklamların sayısı artmaya devam etmiştir. Ancak üretilen reklamlar genellikle tek bir satırı veya tek bir sütunu kapsıyordu ve çok az görsel unsurdan oluşuyordu (Sutton, 2009: 56). Zamanla, pazardaki rekabet arttıkça, reklamlarda görsellerde kullanılmaya başlanmıştır. Yaratıcı tasarımın ortaya çıkması medya, reklam ajansı kavramının ortaya çıkmasını da sağlamıştır (Berger, 2001: 78). İlk reklam ajansı ise 1842'de ABD'de Volney B. Palmer tarafindan kurulmuştur. (Berger, 2001: 83).

19. yüzyılın sonlarında fotoğrafçılık, sinema ve radyo gibi yeni teknolojilerin insan hayatına girmesinin ardından reklamcılık da yeni bir aşamaya evrilmiş̧ir. 1895'te ilk sinema gösteriminden 10 y1l sonra New Jersey'deki West Orange Edison Stüdyoları'nda Admiral sigaralarının reklam filmi çekilmiştir (Karaçor, 2007, s.102).

1900'lere kadar, reklamlar temel olarak ürünlerin kullanımları ve faydaları hakkında mesajlara yer vermiş, aynı zamanda rakiplerine karşı fiyat avantajlarını vurgulamıştır. 1920'lerde, reklamcılıkta toplumda farklı tüketici segmentlerinin varlığını kabul eden yeni bir yaklaşım geliştirilmiş ve buna göre reklamlar tasarlanmıştır. Örneğin lüks mallara yönelik reklamlar yoluyla yüksek gelirli gruplara da hitap edecek reklam türleri tasarlanmıştır. Sanayi devrimi de kentsel nüfusta büyük bir büyümeye neden olmuş, 1920'lerde dünya nüfusunun neredeyse yarıs1 şehirlerde yaşamaya başlamıştır. Kentsel alanlarda daha fazla fabrika kuruldukça şehir kırları yutmaya başlamıştır. Endüstriyel gelişmeler sayesinde nüfus artışıla gelişen bu kentleşme süreci, 20. Yüzyıla en fazla etki eden sosyolojik etkilerinden biri olmuştur. Pazar rekabeti arttıkça, şirketlerin tüketicilerine en uygun şekilde ulaşmak için ürünlerini ve mallarını farklılaştırmaları gerekmiş̧tir. Böylece, ürünlerini ve mallarını ağırlıklı olarak kullanan ve satın alma olasılığı 
yüksek olan kitlelere tüketici analizleri yapmaya başlamışlardır. Bu, reklamcılıkta segmentasyonun doğuşu olarak açıklanmaktadır. 1930'ların başında, reklamlar tüketicileri pazarlama sürecinin merkezi haline getirmeye başlamıştır (Beard, 2016: 122).

Tüketici, reklam mesajlarının tüketicinin belirli bir ürünü satın alma ihtiyacına dayandığı, II. Dünya Savaşı'ndan sonra 1950 ve 1960'larda merkezi statüsünü daha da güçlendirmiştir. 1950'lerde Ted Bates \& Co için çalışan Rosser Reeves tarafından benzersiz satış teklifi konsepti tanıtılmıştır. Reeves, ürünü ve rakipleri arasındaki farklılıkları vurgulayan yeni bir reklamcılık yaklaşımı geliştirmiştir (Schutt v.d, 2016: 45).

Gelişmiş dünyada savaştan sonra endüstriyel büyüme genişledikçe, insanlar tüketim uygulamalarıyla kendi kimliklerini tanımlamaya ve sunmaya başlamışlardır. Bu durum şirketleri rekabet etmek ve daha fazla tüketiciye sahip olmak için reklamları daha yoğun kullanmaya zorlamıştır. Böylece, tüketim kültürü genişlemiş ve reklam her şirket ve marka için pazarlamanın zorunlu bir parçası haline gelmiştir (Schudson, 2018: 131).

\section{Reklamlarda Ünlü Kullanımı}

Ünlü kavramı çok çeşitli tanımlara sahiptir. Türk Dil Kurumu ünlü kavramını "tanınmış, şöhretli, meşhur, şanlı, namlı" şeklinde tanımlamıştır (TDK' dan aktaran, Sezgin ve Yılmaz, 2019: 476). Bir ünlü genellikle meslekte yükselen, insanlar tarafından çok iyi bilinen; iyi veya kötü bir şöhrete sahip olan bir kişi olarak tanımlanır. Ünlü kavramının tanımları ve bu tanımların insanlara göre anlamı dönemsel olarak değişim göstermiştir. Bir zamanlar, yalnızca başarılı tarih hanları, büyük liderler ve savaş alanında önemli zaferler kazanan güçlü komutanlar veya insanlara iyi hizmet eden bilim adamları mistik bir şekilde psikolojik olarak putlaştırılırken; günümüzde bu durum aktörler, aktrisler, şarkıcılar, sporcular için geçerli hale gelmiştir (Kocabaş ve Elden, 1997: 126).

Reklamlarda ünlü kullanım stratejisi, ünlülerin reklamda bir markanın ürünlerini tanıtmak amacıyla yer alması anlamına gelmektedir. Reklamverenler, etkili ürün satışı için birçok tüketici segmentine ve müşteri zihnine ulaşmayı hedeflemektedir. Genellikle, ünlü kullanım stratejisi marka imajını veya kurumsal imajı desteklemek amacıyla kullanılmaktadır (Katırcı ve Yüce, 2016). Daha kapsamlı bir açıklama ile ünlü isimler markaya fiziki özelliklerinin yanı sıra bir ruh ve kişilik kazandırmak amacıyla marka imajı oluşturmak için, satış geliştirme ve halkla ilişkiler amacıyla kullanılmaktadır Reklamlarda ünlü kullanımı tanımı 60'lar ve 80'li yıllardan bu yana çok fazla değişmemiştir. Schlecht'e göre ünlüler, belirli bir grup insanın büyük bir kısm1 tarafından kamuoyunun tanınmasından hoşlanan insanlardır ve çekicilik, sıra dışı yaşam tarzı gibi özellikler onların öne çıkan özellikleridir (Kansu ve Mamuti, 2013: 677). Burada kastedilen ünlü kişi kavramı ile tüketicinin satın alma kararı üzerinde olumlu etki yaratacak referans grubundan bahsedilmektedir. Bu grup içerisinde başarılı iş insanları, sinema ve tiyatro sanatçıları, sporcular ve gazeteciler gibi çok farklı yelpazeden isimler bulunmaktadır (Solak, 2016: 259).

Ünlü kullanımı stratejisinde reklamverenler, ünlülerin çekiciliğini ve reklam görüntüleme sayısını artırmayı ve reklamı müşteri zihninde kolayca hatırlatmayı amaçlamaktadır. Aynı zamanda, ünlülerin kullanılması ünlülerin hayran gruplarının ürüne yönelik dikkatini arttırır. 
Marka ile hiçbir ilgisi olmayan insanlar, ünlüleri kullandıktan sonra markayla ilgilenmeye başlayabilirler (Solak, 2016:264). Seçilen ünlüler sadece tanınmakla kalmamalı, aynı zamanda ikna edici olmalı, güçlü bir imaja, güvenilir, uzmanlığa ve cazibeye sahip olmalı ve müşterilerin zihninde etkili bir algı oluşturmalıdır. Tüketicilerin güvenini ve akılda kalıcı reklamı kazanmak ünlüler için çok önemli faktördür. Reklamda kullanılacak markanın ürünü ile ünlü her zaman orantılı olmalıdır.

Tüketicilerin tanıdığı, beğendiği ve kendisine rol model aldığı ünlü isimlerin reklamlarda kullanılması ilk olarak reklamın ikna ediciliğini arttırmakta ve ünlü kişi ile özdeştirme yolu ile ürün satın almaya ikna edilmesine yol açmaktadır. Ünlü kullanım stratejisinde ünlü kişi sadece reklamda görünmekle kalmamakta, ürünün diğer pazarlama çalışmaları içinde de yer alabilmektedir (İplikçi, 2015: 72) Yıldız stratejisi olarak da adlandırılan bu durum, markaların büyük önem verdiği bir araç haline gelmiştir. Yıldız stratejisi, pazarlama iletişimi öğelerinin strateji ve hedeflerine ulaşmak için reklamın hedef kitlesine nasıl ulaşacağını belirlemektedir (Zahaf ve Anderson, 2008: 58).

Ünlü insanlar bazen markanın fiziksel özelliklerine ek olarak bir ruh ve kişilik yaratmak, diğer bir deyişle marka imajı oluşturmak ve bazen halkla ilişkiler ve satış geliştirme faaliyetlerini yönetmek ve yönetmek için kullanılır. Yıldız stratejisi, ürünlerin tüketiciler tarafindan daha kolay algılanabileceği veya daha kolay hatırlanabileceği bir gerçektir. Ayrıca, yıldız stratejisi veya iletişim faaliyetlerinde yer alan ünlülere ödenen sözleşme ücretleri bazen astronomik rakamlara ulaştığı düşünüldüğünde, etkilerinin sağlanmasında dikkate alınması gereken bazı hususlar vardır. Aksi takdirde, harcanan tüm para ve emek boşa gidecektir. Tanıtım etkinliklerinde kullanılan yıldızın kişisel başarısı, çoğu durumda tanıtılan ürünün başarısıyla doğrudan bağlantılıdır. Bu nedenle, ünlü kişinin marka adını lekeleyecek herhangi bir faaliyetten kaçınması beklenmektedir (Kocabaş ve Elden, 1997: 12). Buna bir örnek vermek gerekirse geçmişte Britney Spears, Pepsi ile anlaşmalı olduğu dönemde Coca-Cola içerken görüntülendiği için, Pepsi ile anlaşması sona ermiştir (Solak, 2016: 261).

Özellikle televizyon ekranlarında neşeli, hayat dolu ve güzel insanların dinamik görüntüleri kullanılır. Bunun marka için önemli bir görsel strateji olduğu düşünülmektedir. Bu nedenle ünlü kullanımı markanın rakiplerine kıyasla hem farklılaşma hem de kurumsal imaj açısından önemli bir avantaj olduğu düşünülebilir (Hung, Chan ve Tse, 2011; 621). Ünlü (yıldız) kullanımı reklam ve markaya karşı olumlu tutum ve ikna oluşumunda çok etkili bir yöntemdir. Bu yöntemin dört tip faydası vardır: (Zahaf ve Anderson, 2008: 6-7).

-Hızlı dikkat: Ünlü kişinin reklamdaki varlığının ve markaya yüklenen değer arasındaki farkın tanınması gerçekleşir

- Hızlı bağlantılar geliştirme: Reklam ve izleyici arasında bir fikir veya yakınlık olmamasına rağmen, yıldız kullanımı nedeniyle bağlantı kurulur.

- Hızlı marka değeri çağrışımları: Yaratıcı bir hikâye anlatımında doğru yıldızın kullanılması marka mesajını daha hızlı iletebilir

- Hızlı marka farklılaşması: Marka diğerlerinden kolayca sıyrılabilir 
Reklamlarda ünlü kullanımının avantajları ve dezavantajları marka, ünlü, ürün, hizmet, zaman, yapım gibi öğelerin anlık durumlarına bağlı olarak çeşitlilik göstermektedir. Genel anlamda akademik kaynaklar ve şirket raporları incelendiğinde, reklama olan ilgi ve dikkatin arttırılması, marka farkındalığının yaratılması, satın alma eğiliminin sağlanması gibi sonuçlar bakımından ele alındığında, ünlülerin reklamlarda doğru bir şekilde kullanılmasının reklamların daha etkili olacağı düşüncesini ön plana çıartmaktadır.

Reklamlarda ünlü kullanımı sıklıkla olumlu ve etkili bir strateji olarak vurgulansa da belirli durumlarda olumsuz bazı durumlar da ortaya çıkabilmektedir. Erdoğan tarafindan yapılan değerlendirmelerde ünlü kullanımının potansiyel avantaj ve dezavantajları şu şekilde açıklanmıştır.

Tablo 1: Ünlü Kullanımı Avantaj ve Dezavantajları (Erdoğan, 1999: 295)

\begin{tabular}{|c|c|c|}
\hline Potansiyel Avantajlar & Potansiyel Tuzaklar & Önleyici Taktikler \\
\hline Dikkati arttırır & Markayı gölgeler & Ön testler ve dikkatli planlama \\
\hline İmajı düzeltir & Kamuoyu ile uyumsuzluk & $\begin{array}{l}\text { Kontratlara satın alma sigortası ve } \\
\text { provizyon şartı konulması }\end{array}$ \\
\hline Markayı tanıtır & $\begin{array}{l}\text { İmajın değişimi ve fazla } \\
\text { teşhir olunması }\end{array}$ & $\begin{array}{l}\text { Rolünün iyice açıklanması ve } \\
\text { başka markalarda yer almasının } \\
\text { yasaklanması }\end{array}$ \\
\hline $\begin{array}{l}\text { Markayı yeniden } \\
\text { konumlandırır }\end{array}$ & $\begin{array}{l}\text { İmajın değişimi } \\
\text { kamuoyu kaybı }\end{array}$ & $\begin{array}{l}\text { Ünlünün yaşam döngüsünün } \\
\text { hangi aşamasında olduğu ve bu } \\
\text { aşamanın ke kadar } \\
\text { sürebileceğinin incelenmesi }\end{array}$ \\
\hline $\begin{array}{l}\text { Global kampanyaları } \\
\text { güçlendirir }\end{array}$ & Pahalı & $\begin{array}{l}\text { Yer alacak ünlüleri pazardaki } \\
\text { izleyici için çekici olduklarından } \\
\text { değil, global hedef kitleye uygun } \\
\text { oldukları için seçmek }\end{array}$ \\
\hline
\end{tabular}

Reklamlarda ünlü kullanımı günümüz pazarlama dünyasında ve medya ortamında işletmelerin rakip işletmelerden sıyrılmasını ve iletişim gücünün artmasını sağlar. Firma imajını onarma ve oluşturmada da reklamlarda ünlü kullanılması uygulanan yöntemlerden biridir. Küresel pazarlara girişte de o ülkede tanınan ve sevilen bir ünlü ile çalışmak büyük katkılar sağlamaktadır (Sezgin ve Yılmaz, 2019: 477). Yapılan araştırmaların geneli de ünlü kullanımının reklama yönelik tutum, markaya yönelik algı ve satın alma niyeti açısından olumlu etkiler ortaya çıkardığını göstermiştir. Ünlü kullanımı, anlam aktarımı aracılığıyla imaj yaratma kapasitesini de arttırmaktadır. Dolayısıyla markalar, ünlüleri reklamlarında kullanmayı tercih etmektedir (Armağan ve Gürsoy, 2017: 1045). 


\section{Reklamlarda Ünlü Kullanımı Gelişim Hikâyesi}

Reklam kampanyalarında ünlü kullanımı en yaygın kullanılan pazarlama stratejilerinden biridir. Ünlü kullanımının geçmişi incelendiğinde, bu stratejinin 17. yüzyılda başladığı kabul edilmektedir.

1760'larda Wedgwood markasının kurucusu Josiah Wedgwood şirketine marka değeri yaratmak amaciyla kraliyet ünlülerini kullanmıştır. 1975-1900 arası dönemde ticaret kartları ürünler ile beraber tüketicilere ulaştırılmış, bu kartlarda ünlülerin resimleri ve ürünlerin açıklamaları yer almıştır. O yılın ünlü isimleri Lily Langtry ve Sarah Bernhardt bu kartlarda ürün açıklamalarında kullanılmıştır. Bu dönemde markaya müşteri sadakatini sağlamak için beysbol oyuncu kartları da kullanılmıştır. 1930'ların başında, reklamlarda kullanılan ünlüler ağırlıklı olarak sporcular iken, 1945 sonrasında Charlie Chaplin gibi film yıldızları ön plana çıkmıştır. 1965 yılında renkli televizyonun pazara sunulması ardından, televizyon yıldızları ve eğlenceleri, insanlarla iletişim kurmak ve markaların ürünlerini tanıtmak için tercih edilmeye başlanmıştır. 1975 y1lına gelindiğinde her 7 TV reklamından birinde ünlü bir isim kullanılmıştır. 1980'lerde şirketler ünlülerden esinlenerek ürün yapmaya yönelmiştir. Örneğin, Standart Brands Inc. yeni bir şekerleme çubuğu yaratmış ve New York Yankee süper starı olarak tanınan Reggie Jackson'dan esinlenerek ürüne "Reggie" adını vermeye karar vermiştir. 1984'te Nike, ünlü basketbolcu Michael Jordan ile marka imajı yaratmayı tercih etmiş, ünlü sporcu Nike'ın sembolü olmuş ve markanın tüm dünyada marka imajının tanınmasını sağlamıştır. Özellikle markalar sporla ilgili ürünlerde tanıtım için sporcuları kullanmıştır (Vemuri ve Madhav, 2014).

Markalar ürünlerini tanıtmak ve markanın simgesi haline gelmek için ünlüleri kullandığından, pazarlama rekabeti artmış ve bu durum ünlü kullanım talebini ve dolayısıyla ünlülerin gelirlerini arttırmıştır. 1990'ların sonuna gelindiğinde ise markalar ünlüleri markanın sözcüsü olarak kullanmaya yönelmiştir.

\section{Reklamlarda Ünlü Kullanım Modelleri}

Televizyon reklamlarının ortaya çıktığı günden bu yana ünlü kişiler marka, ürün ve hizmet tanıtımlarında sıklıkla kullanılmaktadır. Televizyon reklamlarının yanı sıra diğer ortamlarda yayınlanan reklamlar ve halkla ilişkiler faaliyetlerinde de araştırmacılar yaklaşık yarım asırdır ünlülerin bu faaliyetlerde kullanılması üzerine çeşitli araştırmalara imza atmıştır. Yapılan 'reklamlarda ünlü kullanımına' yönelik akademik araştırmalarında literatüre katkıda bulunan modeller geliştirilmiştir. Bu modeller aşağıdaki gibi özetlenmiştir.

\subsection{Kaynak Güvenilirliği Modeli}

Kaynak güvenilirliği alıcının mesajı kabul etmesini etkileyen olumlu özellikler olarak açıklanır. Model mesajın etkinliğinin, tanıtıcının algılanan uzmanlığı ve güvenilirliğinin düzeyine bağlı olarak değiştiğini öne sürer.

Hovland tarafından geliştirilen kaynak güvenilirliği modeli, kaynağın yani ünlünün uzmanlık ve güvenilirliğine bağlı durumdadır. Birinin bir konu ile ilgili doğru söylediğine yönelik kuvvetli bir alg1 oluşması durumunda o kişi konunun uzmanı olarak değerlendirilir. Bir kişinin bu yönde bir istek taşıdığına yönelik kuvvetli alg1 varsa o kişi güvenilir olarak değerlendirilir. 
Güvenilir kaynaktan gelen bilgiler ise karşı tarafın inançlarını, tutumlarını ve davranışlarını daha fazla etkileyebilme gücüne sahiptir (Zengin, 2018: 421).

İletişim kaynağı, özel uzmanlığı ilgilendiren bir konu olduğunda, uzman kaynak otorite ve inanılırlıkla kuşanmış olacaktır. Bu yüzden de kaynaktan gelen iletişim güvenilir ve inandırıcı olarak ilişkilendirilecektir (Hung, Chan ve Tse, 2011: 8). Bu anlamda güvenilirlik, dinleyicinin konuşmaciya ve iletiye duyduğu güveni ve onu kabul etme derecesini ifade etmektedir.

Hangi faktörlerin kaynak güvenilirliğini oluşturduğu ve hangi faktörlerin diğerlerinden daha önemli olduğu, ünlü kullanımı sürecinin tek boyutlu olmasından ve kesin kanıtlarla açıklanamamasından dolayı hala belirsizliğini korumaktadır. Kaynak güvenilirliğinin, tüketicilerin tutum ve davranış niyetlerinde doğrudan bir etkisi olduğu ispat edilse de reklamcıların ünlü seçiminde etkili de olsa tek faktör olarak göz önünde bulundurulmamalıdır (Erdoğan, 1999: 298).

\subsection{Kaynak Çekiciliği Modeli}

McGuire tarafından oluşturulan kaynak çekiciliği modeline göre kaynağın tanınırlığ1, sevilebilirliği veya benzerliği onun etkinliğini belirlemektedir (Zengin, 2018: 421). Model mesajın etkinliğinde kaynağı çekici kılan fiziki niteliklerin de önemli olduğunu varsayar. Ünlü bir marka yüzünün fiziksel çekiciliğinin markayı hatırlama, markaya yönelik tutum ve satın alma niyeti üzerinde olumlu bir etkisi vardır (Armağan ve Gürsoy, 2017: 1046).

Çekiciliğin önemi, büyük ölçüde göze hitap eden bir reklam ortamı olmasından dolay1 özellikle televizyon reklamlarında daha da ön plana çıkmaktadır. Televizyon reklamlarında çekici ünlülere daima daha sık yer verilmektedir. Yapılan araştırmalarda fiziksel olarak çekici olan ünlü kişilerin reklamlarda yer alması, çekici olmayanlara göre inançları değiştirme hususunda daha başarılı olmaktadırlar. Ancak bu noktada çekicilik sadece fizikselliği değil, kişisel beceriler, olumlu hisler uyandıran kişilik, cesaret, etik değerlere olan bağlılık, takdirle karşılanan yaşam tarzı ve benzeri nitelikleri de kapsamaktadır (Erdoğan, 1999: 299).

\subsection{Anlam Transferi Modeli}

Reklamlarda ünlü kullanımına yönelik bir diğer model olan anlam transferi modelinde anlamın kültürel dünyada başladığı ve ürünlere transfer olduğu; ardından ise tüketicinin yaşamına girdiği kabul edilmektedir.

Ünlüler, kültür içinde sembolik simgelere, popülerliğe sahip olan bireylerdir ve reklamda, sahip oldukları sembolik anlamları tanıttıkları ürüne transfer etmektedirler. Ünlü kullanımları, anlam transferi genel sürecinin özel örneklerindendir. Bu modele göre, tüketici toplumlardaki kültürel anlam hareketinin izlediği konvansiyonel bir yol bulunmaktadır (Erdoğan, 1999: 305). Anlam, egemen olan kültür tarafından inşa edilen fiziksel ve sosyal dünyaya dayanmaktadır. Sonrasında reklam ve moda sistemleri yoluyla kültür tarafından inşa edilen dünyadan tüketim mallarına, oradan da tüketicilerin eforları ile bireysel tüketici hayatına aktarılmaktadır (Kazanawa, 2005:23). 
Anlamın kültürel dünyadan ürünlere aktarılması, reklam ve moda sistemi ile gerçekleşir. Anlamın ürünlerden tüketiciye aktarılmasıysa tüketicinin çabaları ile gerçekleşmektedir (Zengin, 2018: 422).

\section{4. Ürün/Marka Uyumu Modeli}

Ürün/marka Uyumu Modeli, ünlü imajının aktardığı mesajın ve ürün imajının etkili reklamlarda yakınsaması gerektiğini, kısacası ünlü imajı arasında çekicilik tabanında bir uyum gerektiğini öne sürmektedir.

$\mathrm{Bu}$ modelde ünlü ve marka arasındaki uyumun markanın imajını olumlu etkilediği belirtilmektedir. Bu uyumun yüksek olması reklama yönelik tutum ve satın alma niyetinin olumlu olmasını sağlayacaktır. Dolayısıyla bir ünlüyü seven kişilerin onu bir marka ile uyumlu görme ihtimali yüksektir.

\section{Reklamlarda Ünlü Kullanımı ve İlgili Yapılan Akademik Araştırmalar ve Elde Edilen Sonuçlar}

Ünlülerin reklamcılıkta etkili olup olmadıkları ve nasıl etkili oldukları konusunda birçok akademik çalışma yapılmıştır. Londra Ekonomi Okulu'ndan evrimsel bir psikolog olan Kanazawa (2005), insanın sosyal onay isteğinin avc1-toplayıcı olduğumuz zamanlara kadar gitmesi üzerine değerlendirmeler yapmıştır. Kanazawa'ya (2005) göre, bilinçsizce TV'de gördüğümüz insanların arkadaşlarımız olduğunu düşünüyoruz ve onlar tarafından verilen ürün mesajlarına açığız, çünkü normalde tanıdıklarımıza güveniyoruz. Kanazawa'nın çalışması, tüketicilerin Beyonce'i ekranda bir L'Oreal reklamında gördüklerinde, beyinlerinin MR'ları alınırsa dopamin gibi olumlu duyguları tetikleyen salgıların büyümesini izlemek mümkün olacağını göstermiştir. Bu nedenle, ünlülerin reklamcılıkta kullanılması, tüketicilerin onayladıkları ürünlere karşı daha olumlu bir tutum sergilemekte ve satın alma eğilimi artmaktadır.

Solak (2016) reklamlarda ünlü kullanımının tüketiciler üzerindeki etkisini belirlemek amaciyla yürüttüğü araştırmasında iletişim fakültesi öğrencilerine yönelik bir anket çalışması yapmıştır. Bulgulara göre Halkla İlişkiler ve tanıtım bölümü öğrencilerinin yüzde 80,5 gibi yüksek bir oranda televizyondaki reklamlardan etkilenmektedir. Bu oran Radyo Televizyon ve Sinema öğrencilerinde yüzde 58 iken Gazetecilik bölümü öğrencilerinde yüzde 54 seviyesindedir. Ayrıca katılımcilar, bir reklamdan etkilenmeleri konusunda yüzde 20,7 reklamda ünlü kullanılmasına, yüzde 5,3 reklamın yayınlanma sıklığına, yüzde 58 reklamın verdiği mesaja, yüzde 6,7 reklamın müziğine, yüzde 9,3 reklamın sloganına bağlı olduğunu belirtmiştir.

Sezgin ve Y1lmaz (2019) reklamlarda ünlü kullanımının tüketici üzerindeki etkisinin belirlenmesi amacıyla Uşak Üniversitesi İletişim Fakültesi bölümü öğrencilerine yönelik bir anket çalışması gerçekleştirmiştir. Elde edilen bulgulara göre katılımcıların reklamlarda etkilendikleri faktörler yüzde 49,8 reklamın verdiği mesaj, yüzde 27 reklamın müziği, yüzde 9,8 reklamın sloganı, yüzde 7,5 yayınlanma sıklığı ve yüzde 5,5 de ünlü kullanımı olmuştur. Ayrıca reklamlarda ünlü kullanılmasına ilişkin katılımcılara sorulan soruya katılımcıların yüzde 41'i reklamı daha kolay hatırlamama yardımcı olur derken, yüzde 22,4'ü 'bu tür reklamlar beni etkilemez', yüzde 20,3'ü 'oynayan kişiye olan tutumuma bağlı olarak reklam daha çok ilgimi 
çeker', yüzde 10,3'ü 'reklamı yapılan ürüne güvenmemi sağlar' ve yüzde 6's1 da 'reklam inandırıcılık kazanır' yanıtını vermiştir.

Katırc1 ve Yüce (2016) tarafında GQ Türkçe edisyonunda 16 sayının içerisinde 702 dergi reklamının incelendiği çalışmada 24 reklamda spor ünlüsünün kullanıldığı belirlenmiştir. Buna göre tüm reklamların içerisinde spor ünlüsünün kullanıldığı reklamların oranı yüzde 3,29 olarak bulunmuştur. Bu spor ünlüleri içerisinde 14'ü futbol, 1'i basketbol, 1'i dağcllık, 1'i tenis, 1'i spor medya spikerliği/yorumculuğu, 1'i atletizm ve 1'i motosiklet branşındadır.

İşler (2014) reklamlarda ünlü kullanımını cinsiyet değişkenine göre incelediği çalışmasında reklamlarda ilgi uyandıran unsur olarak yüzde 33 reklamın konusu, yüzde 14 tanıtan kişi, yüzde 11 müzik, yüzde 10 mekan özelliğinin önemli olduğunu belirtmiştir. Ünlü kişilerin oynadığ1 reklamlara ilişkin tutumlar konusunda yüzde 24,9 'u ünlü birinin oynadığı reklamın dikkatini çektiğini söylerken, yüzde 13'ü sadece ünlü kişiyi izlediğini açıklamıştır. 'Hiç izlemem' diyenlerin oranı ise yüzde 13 iken, sadece reklamı izleyenler katılımcıların yüzde 29'unu oluşturmuştur.

Kurtbaş ve Barut (2010) ünlü kullanılan televizyon reklamlarının marka farkındalığı ve marka sadakati oluşturmadaki rolünü inceledikleri araştırmalarında katılımcıların yüzde 26,6's1 reklamda yer alan ünlüyü sevdikleri takdirde o marka ve ürüne karşı güven duygularının oluştuğunu belirtmiştir. Buna karşın, katılımcıların yüzde 62,8 'i, ünlünün markanın güvenilirliğine bir katkısı olmadığını ifade etmiştir.

\section{Türkiye’de Reklamlarda Ünlü Kullanımı}

Türkiye'de reklamcılığın gelişimi kitle iletişim araçlarının gelişimi ile birlikte ortaya çıkmıştır. 1950'lere kadar, sanayi işletmelerinin büyük bir kısmının devlet tarafından tekelleştirilmesi, profesyonel ve modern anlamda sınırlı bir reklam ihtiyacına yol açmıştır. Çok partili dönemde başlayan liberalleşme reformlarından sonra reklam Türkiye'de ekonomik yaşamın vazgeçilmez bir unsuru haline gelmiştir (Tayfur, 2006: 34). Ayrıca, özellikle II. Dünya Savaşı'ndan sonra okuryazarlık oranlarındaki artışla birlikte gazete satışları da artmış ve bu da reklamcılığın ilerlemesine neden olmuştur (Schutt, Roberts ve White, 2016: 456).

Türkiye'de radyolar ilk 27 Ocak 1957'de reklam yayınlamaya başlamıştır. Daha sonraki yıllarda ise önemli bir reklam mecrası olmuştur (Şimşek, 2006: 45). Tarihsel bazda reklamcılıktaki en önemli gelişme televizyonda reklam yayınlanmaya başlaması ile yaşanmıştır. Televizyon reklamcılığı Mart 1972'de TRT'nin kararıyla başlamış ve zaman içinde yaygınlaşmıştır (Akbulut ve Balkaş, 2006: 89).

1980'lerde, pazarı dış hizmetlere ve ürünlere açan Türkiye ekonomisinin liberalleşmesi reklamcılığı da etkilemiştir. İç pazarda hızlanan rekabetin yanı sıra, Turgut Özal döneminde serbest piyasa ekonomisinin yaygınlaşması çokuluslu şirketleri Türkiye'ye taşımış ve o şirketlerin ürünleri ürün ve hizmetlerini kapsamlı bir şekilde tanıtmaya teşvik etmiştir (Iş1ktaş, 2018:76). Ayrıca, çok uluslu reklam ajansları yerli ortaklarla iş ortaklıkları kurmaya başlamıştır, Bu gelişmelerle beraber Türk reklam sektörünü 1980 'lerde yeni bir döneme girmiştir (Işıktaş, 2018:77). 


\section{YAZ SUMMER 2021-SAYI/ ISSUE 27-SAYFA PAGE 101-123}

Türkiye'de reklamda ünlü bir kişi kullanımı ilk kez 1972'de gerçekleşmiştir. O dönemde reklamlarda oynayan ünlü kişiler Zeki Müren, Seyyal Taner ve Nükhet Duru olmuştur (Işsktaş, 2018, s. 80). 1980'lerle beraber Kadir İnanır, Müjde Ar, Türkan Şoray ve Filiz Akın gibi ünlü aktörler, şarkıcılar ve aktrisler çeşitli ürün kategorileri için TV reklamlarında görülmeye başlamıştır. Özellikle 1980'lerde, erkek ünlüler televizyon, araba reklamlarında kullanılırken, ünlü aktrisler de emlak ve politik reklam kampanyalarında ev tasarımı, temizlik, kişisel bakım, sebze ve tekstil ürünlerinin reklam yüzü olmuştur.

Günümüzde ünlü isimler televizyon reklamlarında yer almaya devam etmektedir. Buna göre ağırlıklı olarak ses sanatçıları, televizyon dizi oyuncuları ve sporcular reklamlarda boy göstermektedir. 2020 ve 2021 yıllarında reklam kampanyalarında kullanılan ünlüler aşağıdaki tabloda derlenmiştir.

\begin{tabular}{|c|c|c|}
\hline \multirow[b]{2}{*}{ Marka } & Kullanılan & \multirow[b]{2}{*}{ Ünlünün Faaliyet Alanı } \\
\hline & Ünlü & \\
\hline Colastin & Hadise & Müzik \\
\hline Bambi Yatak & Hülya Avşar & TV \\
\hline Vestel & Beyazıd Öztürk & TV \\
\hline Elidor & Zeynep Bastık & Müzik \\
\hline Ergül Mobilya & Ajda Pekkan & Müzik \\
\hline Boron & Ümit Besen & Müzik \\
\hline Turco & Haluk Levent & Müzik \\
\hline Avva & Murat Boz & Müzik \\
\hline Oppo & Sila & Müzik \\
\hline Oppo & Acun Ilicalı & $\mathrm{TV}$ \\
\hline Thodex & Simge & Müzik \\
\hline Thodex & Bahar Şahin & Oyuncu \\
\hline Thodex & Özge Ulusoy & Manken \\
\hline Thodex & Ebru Şallı & Manken \\
\hline Thodex & Deren Talu & Ünlü oyuncu Defne Samyeli'nin kızı \\
\hline HepsiBurada.com & Cem Y1lmaz & Oyuncu \\
\hline Yemek Sepeti & Bülent Ersoy & Müzik \\
\hline Belonna & Şevval Sam & Müzik + Oyuncu \\
\hline Ocasso & Hande Yener & Müzik \\
\hline
\end{tabular}




\begin{tabular}{lcl}
\hline Bepanthol & Aslı Enver & Oyuncu \\
\hline & Serenay & \\
Head\&Sholders & Sarıkaya & Oyuncu \\
\hline
\end{tabular}

Tablo 2. 2020-2021 Yılları Arasında Reklam Kampanyalarında Kullanılan Ünlüler

\section{Sıla ve OPPO Reklamının Vak’a Analizi}

Çalışmanın bu bölümünde akı1lı telefon markası OPPO'nun televizyon reklamlarında yer verilen Sıla ve "Sende ne yetenekler varmış Sıla?" başlıklı reklam filminden hareketle reklamlarda ünlü kullanımı konusunda üniversite öğrencileri özelinde gerçekleştirilen nitel araştırmanın bulgularına yer verilmiştir.

2004 yılında Çin'de faaliyete geçen Oppo markası özellikle küresel akıllı telefon pazarına hızlı bir giriş yapmıştır. 2016 yılında Çin'in en büyük telefon üreticisi olmayı başaran Oppo'nun en büyük özelliklerinden biri marka reklam kampanyalarında ünlü kullanmasıdır. Oppo bu stratejisini küresel çapta yürütmüş ve her giriş yaptığı ülke pazarında adını o ülkenin ünlüleriyle yaptığı reklam anlaşmaları veya popüler sponsorluklarla duyurmaya çalışmaktadır.

2015 yılında İspanya Kupası ve Barcelona futbol takımı ile sponsorluk anlaşması imzalayan Oppo, 2019 yılında dünyaca ünlü Fransız Roland Garros tenis turnuvasına sponsor olmuştur. 2011 y1lında piyasaya sürdüğü "Find" adlı telefon modelini dünyaca ünlü oyuncu Leonardo Di Caprio ile tanıtan Oppo, Türkiye pazarındaki ilk büyük marka tanıtım kampanyasını 2019 yılının Ekim ayında başlatmıştır.

Oppo Türkiye'ye merhaba derken ilk marka reklam kampanyasında müzik piyasasının ünlü yorumcusu Sıla ile çalışmış ve Sıla'yı markanın yüzü yapmıştır. Sıla bu reklam kampanyasında 3 milyon liralık bir ücret karşılığında rol almış ve Oppo'yu Türkiye'ye tanıtan reklamlarda rol almıştır (CNNTÜRK,2019).

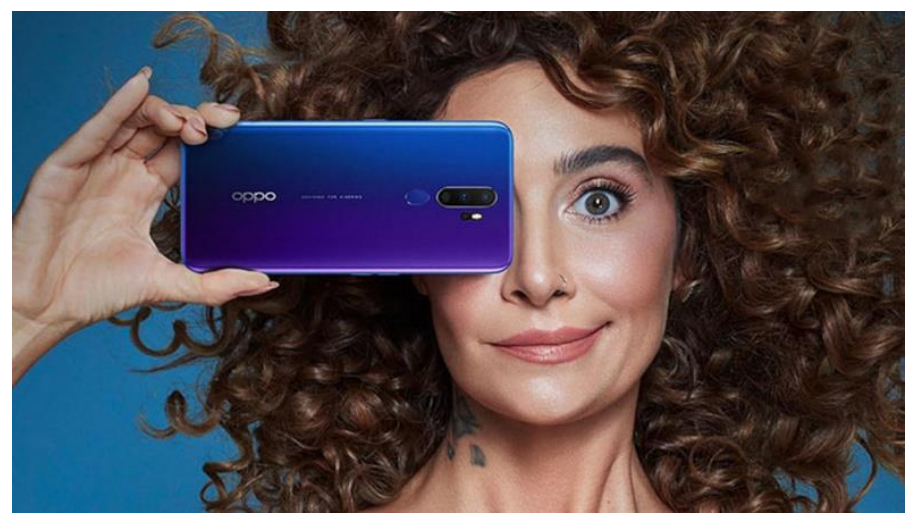




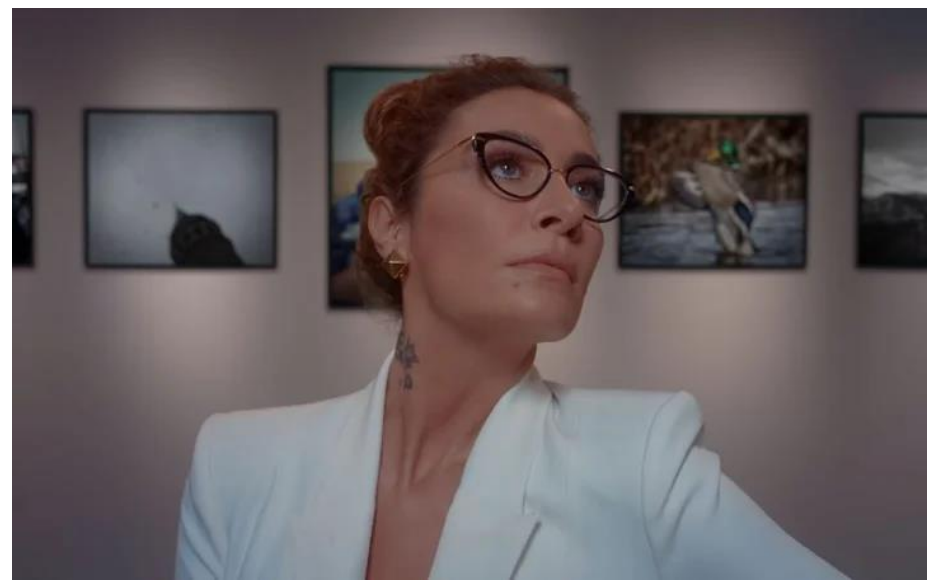

Şekil 1. Sıla'nın Oppo Reklam Kampanyasında Kullanılan Görseller

2020 yılının özellikle ilk yarısı boyunca özellikle televizyon kanallarında ve outdoor mecralarda çok yüksek frekansta kullanılan reklam kampanyasında Sıla'nın Oppo akıllı telefonu kullanırken başından geçen olayları işlemiştir. Reklamda Sıla'nın müzik yorumcusu özelliği hiç kullanılmamış sadece onun görsel kimliği ile markası kullanılmıştır.

Reklam kampanyasının başlamasının bir ay sonrasında Oppo bir basın bülteni yayınlayarak, Sıla ile yapılan bu reklam kampanyası sayesinde Oppo marka telefonların satış rekorları kırdığını belirtmiştir. Firma tarafından daha reklamın yayına girmesinin ardından üç ay bile geçmeden böyle bir basın bülteni yayınlaması ve "satış rekoru" olarak adlandırılan başarı ile ilgili hiçbir veri kullanılmaması yapılan reklam kampanyasına yönelik bir algı kampanyası olduğu konusunu düşündürmektedir.

Oppo Sıla'nın kullanıldığı Oppo marka akıllı telefonlarının reklam kampanyasının başlamasının hemen ardından yayınladığı basın bülteninde “OPPO’nun yenilikçi özelliklere sahip akıllı telefonları için yaptığı tanıtım kampanyaları, markanın hem popülerliğini hem de Türkiye'deki pazar payını artıyor. 40'tan fazla ülkede ve bölgede hizmet veren lider akıllı telefon markası OPPO 2019 yılında girdiği Türkiye pazarında "A Serisi 2020" ve "Reno2" modellerinin tanıtımı için başarılı şarkıcı Sıla ile yapmış olduğu iş birliği ürünlerin satış performansına dikkat çekici bir etkide bulundu. Türkiye pazarına ayrı bir önem vererek ilk kez bir yerel reklam kampanyası gerçekleştiren OPPO, hizmet verdiği kültüre hitap eden kampanyaları ile kullanıcılarının gönlünde taht kurdu. Yaptığı bu etkileyici girişimlerin karşılığını da Avrupa bölgeleri içerisinde ilk yılı olan Türkiye'de satış rekoru başarısıyla aldı." İfadelerine yer verilmiştir (Oppo, 2020).

OPPO Türkiye Genel Müdürü Çinli Weijian Zhou, yaptıkları reklam kampanyalarının etkisi hakkında şunları söyledi:

“Yeni 'A Serisi 2020' modellerimizi duyurmak için OPPO'nun Avrupa bölgesinde ilk defa yerel bir kampanya yaptık. Avrupa pazarında, Türkiye'ye ayrı bir önem veriyoruz. Bunu, OPPO'nun merkez yönetimine de ifade ettik. Türkiye'de yerelleşmemiz gerektiğini söyledik. Böylece ortaya başarılı iki kampanya çıktı. Sila ile yaptı̆̆ımı başarılı reklam kampanyaları sayesinde OPPO'nun ismi artık daha çok biliniyor. Bugün 'OPPO nasıl bir markadır' dediğimizde; 'Kamerası güzel olan telefon' cevapların aliyoruz. Son olarak yeni 'Reno2 serisi' kullanicılarla buluşurken, biz yine yerel 
reklamlarla devam etmek istedik. Bu kez Sila'nın yanı sira Didem Soydan, Hakan Kurtaş ve Uraz Kaygılaroğlu gibi ünlü isimlerle iş birliği yaptık. Bu iş birliklerinin etkisi ile 'A Serisi 2020've 'Reno2' modellerinde OPPO Türkiye olarak Avrupa bölgesinde satış rekoruna imza attı.." (Oppo,2020) açıklamasını yaparak Sıla ile gerçekleştirdikleri reklam kampanyasının çok başarılı olduğunu iddia etmiştir.

$\mathrm{Bu}$ araştırmada akıllı telefon kullanımında birincil hedef kitle konumunda olan üniversite öğrencileri örnekleminde Sıla'nın reklam yüzü olarak yer aldığı Oppo marka reklamın tüketicilerin akıllı telefon marka algısına olan etkisine yönelik bir betimsel araştırma yapılmıştır.

$\mathrm{Bu}$ kapsamda üniversite öğrencilerine yapılan ankette reklam filmine yönelik genel düşünceleri, Sıla ile OPPO arasında kurulan bağın nasıl olduğuna dair görüşleri, reklamın ürünün kendisine olan etkisi, Sıla'nın ürünün hedef kitlesine olan uyumu, reklam filminin senaryosu, reklamda ünlü kullanımının o ürüne yönelik ilgiyi artırıp artırmayacağı, kişisel olarak sevilen bir ünlünün bir reklamda kullanılmasının o ürüne yönelik ilgiyi artırıp artırmadığı ve kişisel olarak reklamı hazırlamaları durumunda reklamda ürün kullanıp kullanmayacakları konusundaki görüşleri sorgulanmıştır. Araştırmada anket yöntemi kullanılmış ve İstanbul il sınırları içinde çeşitli üniversitelerde eğitim alan toplam 316 öğrenciye ankette yer alan 16 soru sorulmuştur. Araştırma reklam kampanyasının aktif olduğu dönemin altıncı ayında 2020 yılının Haziran ve Temmuz aylarında uygulanmıştır. Covid-19 pandemisinin ilk dalgasının azaldığı ve normalleşmenin başladığı dönem olan Haziran ayının on beşinde başlayan anket uygulaması elektronik posta yolu ile uygulanmıştır. Rassal seçilen toplam 360 üniversite öğrencisine yollanan anket formuna cevap veren 316 üniversite ögrencisi ankete dahil edilmiş ve elde edilen bulgular istatistik yazılımı SPPS 25 adlı yazılımı aracılığı ile analiz edilmiştir. Alınan cevaplar kategorileştirilmiş ve en yüksek frekanstan en düşüğe kadar sıralanmıştır. Araştırmanın bulgular bölümünde frekans olarak ortalamanın üstünde olan fikirler değerlendirilmiştir ve araştırmaya katılanların ortalamanın üstünde kalan en çok tekrarlanan yorumları tartışmaya açılmıştır.

\subsection{Araștırmada Elde Edilen Bulgular}

Araştırmaya katılanlara ilk olarak Sıla'nın reklam yüzü olarak kullanıldığı OPPO reklamını genel olarak nasıl buldukları sorulmuştur. Tablo 3'de görüldüğü gibi katılımcıların \%15’i reklamı "kötü”, “\%36,67'si “orta düzey” ve \%48,33’ü “iyi düzeyde” olduğunu düşünemektedir.

Tablo 3: Reklamı nasil buluyorsunuz?

\begin{tabular}{ll} 
& \multicolumn{2}{c}{$\%$} \\
\hline Kötü & 15,00 \\
\hline Orta & 36,67 \\
\hline İyi & 48,33 \\
\hline Toplam & 100,00 \\
\hline
\end{tabular}


Reklamı "kötü” bulanlar, genel olarak bu görüşlerini, reklamın "yaratıcı olmayan" ve "fotoğraf sanatçılarını aşağılayan" bir yönü olduğunu, ayrıca "fazla uzun ve sıkıcı" olduğunu, hatta "markanın değil Sıla'nın reklamı" olduğunu belirtmişlerdir.

Reklamı "orta düzeyde" bulanların neredeyse tamamı genel olarak bu görüşlerini "ürünün tek bir özelliğine (kamerasına) odaklanılmış olduğu" ve "Sıla'nın markanın önüne geçtiği” tezine dayandırmışlardır. Ayrıca reklamın senaryosu için "basit” yorumunu yapmışlardır.

Reklamı "iyi" bulanlar ise "günümüzde herkesin telefon bakarken ilk olarak akıllı telefonun kamerasına bakması nedeniyle", "tek bir özelliğine (kamerasına) odaklanılmış olması”, "ürünün hedef kitlesine doğrudan mesaj yolladığını" belirtmiştir. "Gündelik yaşamdan kesitlerle", "mizahi bir dille", "sevilen bir şarkıcının oynatılmasının" reklamın ve reklam sloganının (OPPO çok iyi yaa!) akılda kalıcılık sağladığını dile getirmişlerdir.

\subsection{Reklam ve Sıla Arasındaki Bağa İlişkin Bulgular}

Reklam ve ünlü arasındaki bağ konusunda üniversite öğrencilerinin genel görüşü Sıla'nın markanın ve ürünün önüne geçtiği yönünde olmuştur.

Sıla'nın markanın ve ürünün önüne geçtiğini düşünenler (yüzde 67,2), "reklamın uzunluğu nedeniyle Sıla'nın fazla ön plana çıktığı", "Sıla'nın mizahi yönünün ağır bastığı”, “ürünün ve markanın görsellerinin reklam filminde çok az gösterildiğì", "Sıla'nın şarkıcı, ürünün ise akıllı telefon olduğu, bu nedenle Sıla'nın ürün hakkındaki görüşlerinin önemli olmadığı (Sıla'nın teknoloji ile ilgili bir iş yapmadığı)" yönünde görüş bildirmiştir.

Ayrıca çarpıcı bir bulgu olarak Sıla'nın reklamda söylediği "Yetenek sadece telefonda mı?", "Kamera ondaysa göz bende" ifadelerinin "çok kötü bir reklam metni olduğunu" ve "reklamın vermek istediği mesajın tam aksini çağrıştırdığını” belirtmiştir.

\subsection{Reklamın Ürün Markası ve İmajı Üzerindeki Etkilere Yönelik Bulgular}

Araştırmaya katılan üniversite öğrencilerinin neredeyse tamamı (yüzde 98,2), reklamda "Türkiye çapında tanınan bir şarkıcının oynamasının ürünün ve markanın tanıtımına olumlu etkileri olduğunu" belirtilmiştir. Ancak reklamın o ürünün özelliklerini anlatma anlamında sınıfta kaldığı dile getirilmiştir (yüzde 74). Örneğin, "kamerası çok iyi dense de kameranın kaç MP olduğunu dahi bilmediklerini”, "ürünün kamera haricinde hiçbir özelliğinin tanıtılmadığı, örneğin kaç GB hafizaya sahip olduğunu dahi bilmediklerini”, "ürünün tek özelliğinin kamerasıymış gibi lanse edilmesi nedeniyle kamera ile işi olmayanların ürünü tercih etmeyeceklerini” dile getirmişlerdir.

\subsection{Sıla'nın Ürünün Hedef Kitlesi ile Uyumuna Yönelik Bulgular}

Sıla ile OPPO akıllı telefon markasının hedef kitlesi arasındaki uyum konusunda katılımcılar iki farklı görüş etrafinda toplanmıştır. Bir grup Sıla'nın ürünün hedef kitlesiyle uyumlu olduğunu belirtirken (yüzde 37), diğer grup ise S1la ile ürünün hedef kitlesi arasında bir bağ olmadığını dile getirmiştir (yüzde 63).

Sıla'nın ürünün hedef kitlesiyle uyumlu olduğunu belirtenler, bu görüşlerini temellendirirken, ürünün kamera odaklı bir telefon olması nedeniyle hedef kitlesinin de genç 
kesim olduğunu dile getirerek "Sıla'nın gençler tarafından sevilen bir sanatçı olması" nedeniyle hedef kitle ile ünlü arasında bir uyum olduğunu savunmuşlardır.

Sıla'nın ürünün hedef kitlesiyle uyumlu olmadığını belirtenler ise, bu görüşlerini temellendirirken, ürünün kamera odaklı bir telefon olması nedeniyle "hedef kitlesinin de fotoğraf sanatı ile ilgilenenler olduğunu", "bu nedenle de fotoğraf sanatçısının reklamda oynatılması gerektiğini" belirtmiştir. Ayrıca reklamda "Sıla'ya fazlasıyla mizahi olarak yer verilmesinin, Sıla’nın normal yaşantısında sergilediği imajla uyumlu olmadığını" belirtmiştir.

\subsection{Reklamın Senaryosu ve Konusuna Yönelik Bulgular}

Katılımcıların reklamın senaryosu ve konusu hakkındaki görüşleri, genel olarak reklamı nasıl buldukları ile ilişkili gibi gözükmektedir. Buna göre genel olarak reklamı iyi bulanların reklamın senaryosu ile ilgili görüşleri de olumludur. Reklamı kötü bulanlar senaryoyu da kötü bulmuştur.

Reklamı "kötü" bulanlar, reklamın senaryosunun da "uzun ve sıkıcı" olduğunu, "gereksiz" ve "basit" olduğunu dile getirmiştir.

Genel olarak reklamı orta bulanlar, senaryodaki eksikleri "Sıla'nın fazla ön plana çıkması”, "kamera dışındaki özelliklerin tanıtılmaması", "basit bir senaryoya sahip olması", "ürünün telefon değil fotoğraf makinesi olduğu izlenimi yarattığı" ve "Sıla'nın fotoğraf sanatçısı olarak değil fotomodel olarak tanıtılsa daha iyi olacağı" olarak sıralamıştır.

Genel olarak reklamı "iyi" bulanlar, reklamın senaryosunu da beğenmiş, "farklı mekanlarda geçmesinin reklama dinamizm kattığını" ve "reklamın alışı olunmayan bir senaryosu olduğunu" savunmuşlardır. Bununla birlikte reklamın senaryosunu "başarılı" bulup bu görüşlerini herhangi bir şekilde temellendirmeyenler de bulunmaktadır.

\subsection{Reklamda Ünlü Kullanımının Ürün Tercihine Olan Etkisine Yönelik Bulgular}

Reklamlarda kişisel olarak sevilen ya da sevilmeyen bir ünlünün kullanılmasının o ürünü tercih edip etmemeye olan etkisine yönelik bulgular değerlendirildiğinde farklı görüşler olduğu göze çarpmaktadır. Bu noktada bir ünlüyü kişisel olarak sevenlerin görüşleri biraz daha objektiflik arz ederken, kişisel olarak bir ünlüyü sevmeyen ve onu antipatik bulanların ürüne yönelik görüşlerinin de olumsuz olduğu görülmüştür.

Kişisel olarak bir ünlüyü sevenler, o ünlüyü reklamda gördüklerinde ürünü tercih etme konusunda iki farklı görüş dile getirmiştir. Buna göre sevdikleri bir ünlüyü reklamda gördüklerinde “o ürünü tercih edeceklerini” belirtenler olduğu gibi, sevdikleri bir ünlüyü reklamda görse de “asıl olanın 'ürün' olması nedeniyle ürün tercihinde bir etkisinin olmayacağını” savunanlar da bulunmaktadır. Buna karşılık kişisel olarak sevmediği bir ünlünün oynadığ1 reklamda "tanıtılan ürüne karşı da bir antipati oluştuğunu", reklam filmini görünce "o ünlüye maruz kalmamak için" kanalı değiştirdiğini, "bu nedenle de ürün hakkında yeterince bilgilenemediğini”, "bilgisi olmadığı için de o ürünü satın almadığını" dile getirmişlerdir. Dolayısıyla sevdikleri bir ünlüyü görenler nispeten daha objektif davranırken, sevmediği bir ünlüyü görenler tamamen sübjektif davranmaktadır. 
$\mathrm{Bu}$ açıdan ele alındığında reklamlarda seçilen ünlülerin toplumun yüzde kaçı tarafından sevildiği yüzde kaçı tarafından sevilmediği konusunun çok önemli olduğu konusu bir kez daha ortaya çıkmaktadır. Ünlüyü sevenlerin o ünlünün rol aldığı reklamın tüketici olma olasıllı̆ı da önemli bir faktör olarak karşımıza çıkmaktadır. Reklamlarda ünlü kullanımda seçilen ünlünün o markaya olan negatif değerinin pozitif değerine göre daha şiddetli olduğunu da söylemekte fayda vardir.

\subsection{Kişisel Olarak Reklam Filminde Ünlü Oynatıp Oynatmamaya Yönelik Bulgular}

Araştırmaya katılanların neredeyse tamamı, kişisel olarak bir markanın sahibi olsa, reklam filmlerinde bir ünlüyü kullanacaklarını dile getirmiştir (yüzde 84,3). Bu görüşlerini temellendirirken, "Türk halkının ünlüleri her zaman sevdiğini”, "sosyal medyanın çok önemli bir silah olduğunu”, "ünlünün popülerliğinden ürünün de faydalanacağını” savunmuşlardır.

\section{SONUÇ}

Günümüzde ürün ve hizmet üreten tüm markalar, ürünlerinin tüketicinin zihninde olumlu bir konum kazanmasını istemektedir. $\mathrm{Bu}$ amaçla işletmeler, ürün tasarımı, paketleme, fiyatlandırma ve dağıtım gibi çeşitli pazarlama faaliyetlerini organize eder ve uygulamaktadırlar. Reklam verenler ve reklam ajansları, özellikle büyük bütçeli reklam projelerinde iletmek istedikleri mesajları, ürün veya hizmeti kullanmış birisinin deneyimlerini kamera önünde anlatması yoluyla hedef kitleye aktarmayı tercih etmektedir. Bu tür bir reklam uygulamasinda sıradan insanlar kullanıldığı gibi, zaman zaman ünlüler de tercih edilebilmektedir. Reklamverenler ürünlerinde rakiplerine karşı rekabetçi bir avantaj yakalamak ve tüketiciye karş1 olumlu bir imaj sunmak için genellikle ünlü kişileri (celebrity) aracı olarak kullanırlar. Ürünleri tanıtan ünlüler, böyle bir görüntünün inşasını desteklemenin yanı sıra güvenilirlik gibi özellikleriyle tüketicinin dikkatini çekmektedir. Bugüne kadar yapılan birçok araştırma da pazarlama da en etkili yöntemlerden birinin ünlü kişilerin reklamlarda kullanılması olduğunu göstermiştir.

Ünlü insanların hayatları hemen her aşaması, çeşitli medya araçları ile toplum tarafindan izlenmektedir. Bu durum bu insanları kitleler için bir kimlik kaynağı haline getirmektedir. Eğer seyirciler bir reklama dahil olan kişiyi beğenir ve takip ederse, kendini tanımlamak için onayladığı ürünü tercih etme eğiliminde olurlar. Pek çok çalışma da ünlü kişilerin reklamlarda kullanılmasının, tüketicinin karar verme süreçleri üzerinde belirli etkileri olduğunu göstermiştir.

Televizyon reklamlarında ünlülerin kullanımı çok daha fazladır. Ünlü kişiler genellikle daha önce oluşturdukları imajla reklamlara katılır ve bu imajlarını o ürünlere veya hizmetlere aktarır. Buna karşılık, en sevdikleri ünlüler gibi görünme arzusu içinde ki tüketiciler, teşvik edilen tüketim davranışını gerçekleştirmeye motive olurlar. Özellikle gençler, böyle bir kendini tanımlama sürecinde ebeveynleri dışında rol modelleri aramaya eğilimlidir. Bu rol modellerini okulda, akran gruplarında veya kitle iletişim araçlarında ve özellikle reklamlarda bulurlar.

Ünlülerin gençler için olası rol modelleri olarak öne çıkan TV reklamlarının kimlik araştırmalarında ve kişisel gelişimlerinde çok önemli bir yeri olduğu özellikle son yıllarda tartışılmaz boyuta gelmiştir. Ünlüleri ürün ve hizmetlerinde destekleyici bir unsur olarak 
kullanan reklam kampanyaları, gençleri o marka, ürün ve hizmetleri tüketmeye teşvik eder. Başka bir deyişle, TV reklamında ünlülerle karşılaşan gençler kendilerini bu şöhret figürleriyle ilişkilendirir ve kendileri tarafından onaylanan teklifleri aldıklarında, aynı zamanda bir kimlik kazandıklarını hissederler. Bu nedenle, “ünlü onayını" şirketler ve markalar, özellikle genç tüketiciler arasında farkındalık, tanıma ve hatırlama düzeylerini büyütmek ve bunun sonucunda satış oranlarını arttırmak için önemli bir strateji olarak kullanmaktadır.

Bu çalışmada ünlü bir müzik yorumcusu olan Sıla'nın Çinli OPPO adlı akıllı telefon markasının Türkiye'de yaptığı ilk reklam kampanyasında kullanılması ile ilgili yapılan araştırmada ünlü kullanımının markaya olan etkisi incelenmiştir. Araştırmaya katılanların tamamı kendi şirketleri olması veya bir reklam ajanslarının olması durumunda hazırlayacakları reklam kampanyalarında mutlaka bir ünlü kullanacağını belirtmiştir. Sıla ve OPPO'nun reklam kampanyasında ki buluşmaya yönelik bulgular değerlendirildiğinde araştırmaya katılanların yüzde 48,33'ü reklamı başarılı bulurken yüzde 51,67'si reklamı orta ve kötü olarak değerlendirilmiştir. Reklamda Sıla'nın ünlü olarak kullanılmasına yönelik düşünceler ise olumlu ve olumsuz yönde birbirine eşdeğer oranda çıkarken, reklamın senaryosuna yönelik düşünceler genelde olumsuz olmuştur. Ürünün reklamında Sıla'nın gereğinden fazla ön planda olmasını eleştirenler, gerçek hayatta çok ciddi bir insan olduğu halde Sıla'nın reklam filminde komik olmaya çalışmasını yadırgamışlar, reklamda Sıla'nın bir fotoğraf sanatçısı gibi gösterilmesinin gerçek fotoğraf sanatçısına yönelik bir haksızlık olduğunu savunmuşlardır. Üniversite öğrencileri reklam filminde ürünün sadece kamerasına vurgu yapılmasının da reklamı sıkıcı ve eksik yaptığını savunurken, reklamda bir ünlünün oynatılmasının doğru bir strateji olduğunu çünkü Türkiye'de insanların ünlüleri sevdiğini belirtmişlerdir. OPPO reklamında Sıla'nın ünlü olarak tercih edilmesi konusu ile ilgili ise Sıla'nın markaya uygun olduğunu savunanların oranı yüzde 37 iken, Sıla'nın markayla uyumlu bir ürün olmadığını savunanların oranı yüzde 63 olmuştur.

$\mathrm{Bu}$ araştırmada reklamlarda ünlü kullanımına yönelik düşüncelerin Oppo Reklamı örneği üzerinden betimlenmiştir. Bu betimleme de genel kanaat reklamlarda ünlü kullanımının olumlu dönüşler sağlayacağı yönündedir. Bu araştırma bir kanaat betimlemesi yaparken, reklamlarda kullanılan ünlülerin o ürün veya hizmetin satışlarını ve marka algısını nasıl etkilediği konusu ise ayrı ve önemli bir çalışma konusudur. Bu veri aslında marka ile ünlü arasında kurulan bağın satışlara nasıl yansıdığının ve marka inşasındaki etkisini farklı araştırmalarla belirlemek ve ünlü kullanımına olan düşüncelerle ortaya çıkan sonuçların kıyaslanması tavsiye edilmektedir.

\section{KAYNAKÇA}

Akbulut, N. \& Balkaş, E. (2006) Adım Adım Reklam Üretimi. İstanbul: Beta Yayınları.

Arens, W. F. (1996) Contemporary Advertising, Massachusetts: Irwin McGrow Hill.

Armağan, E.\& Gürsoy, Ö. (2017) Reklamlarda Ünlü Kullanımının Tüketicilerin Satın Alma Kararına Etkisi Üzerine Bir Araştırma. Global Business Research Congress. (3): 10431057.

Barres, M.C. (2006) An Introduction to the Early History Newspaper Advertising. Brent Museum and Archieve Occational Publishing. 
Berger, W. (2001). Advertising Today. New York: Phaidon Press.

CNNTÜRK (2020). Sıla'dan 3 Milyon TL'lik Anlaşma. https://www.cnnturk.com/saglik/siladan3-milyon-tllik-anlasma?page=5 Erişim Tarihi: 22.04.2021

Erdoğan, Z: (1999) Celebrity Endorsement: A Literature Review, Journal of Marketing Management, XV (4): 291-314.

Hung, K., Chan, K.W.\& Tse, C.H. (2011) Assessing Celebrity Endorsement Effects in China. Journal of Advertisement Research. 51(4): 608-623.

Işıktaş, S. (2018) Türkiye'de Reklam Tarihi Gelişimi ve Televizyon Reklam Araştırmaları. Hiperlink Yayınları.

İplikçi, H.G. (2015) Reklamlarda Tüketiciyi İkna Etmek İçin Kullanılan Stratejiler ve Reklam Örnekleri. Sosyal ve Beşeri Bilimleri Dergisi, 7 (1): 66-77.

İşler, D.B. (2014) Televizyon Reklamlarında Ünlü Kişilerin Kullanılmasının Satın Alma Davranışlarına Etkisi: Cinsiyet Ekseninde Bir İnceleme. Süleyman Demirel Üniversitesi Vizyoner Dergisi, 5 (11): 110-134

Kansu, A.S.\& Mamuti, A. (2013) The Use of Celebrity Endorsement as Marketing Communication Strategy by Turkish Airlines. International Journal of Academic Research in Business and Social Sciences. 3(12): 676-683.

Karaçor, S. (2007) Reklam İletişimi. Konya: Çizgi Yayınları.

Katırc1, H. \& Yüce, A. (2016) The Use of Sports Celebrities in Magazine Advertisement: Case of GQ Turkey, Anadolu University, The Turkish Online Journal of Design, Art and Communication, 6 (2): 128-136.

Kazanawa, S. (2005). Celebrity Culture. London: CQ Press.

Kocabaş, F. \& Elden, M. (1997) Reklam ve Yaratıcı Strateji, İstanbul: Yayınevi Yayıncılık.

Kurtbaş, İ.\& Barut, B. (2010) Star-Marka" Stratejisiyle Yapılan Televizyon Reklamlarının Marka Farkındalığı ve Marka Sadakati Oluşturma Sürecindeki Rolü ve Etkisi. Galatasaray Üniversitesi İletişim Dergisi, 13: 107-144.

Okay, A. (2009). Kurumsal Reklamcılık. İstanbul: Derin Yayınları.

OPPO (2020). Sıla Reklamları ile Oppo Satış Rekorları Kırdı. 2 Ocak 2020 tarihli kurumsal basın bülteni.

Schudson, M. (2018) Reprint Retrospective: Historical Roots of Consumer Culture from Advertising, the Uneasy Persuasion. Advertising \& Society Quarterly, 19 (1): 122-135.

Schutt, S., Roberts, S., \& White, L. (2016) Advertising and Public Memory: Social, Cultural and Historical Perspectives on Ghost Signs. New York: Routledge.

Sezgin, M.\& Yılmaz, E. (2019) Televizyon Reklamlarında Ünlü Kullanımının Tüketiciler Açısından Değerlendirilmesi: Uşak Üniversitesi İletişim Fakültesi Öğrencilerine Yönelik Bir Araştırma. Karabük Üniversitesi Sosyal Bilimler Enstitüsü Dergisi, 9(2): 472-488. 
Solak, (2016) Televizyon Reklamlarında Ünlü Kullanımının Satın Alma Davranışı Üzerine Etkisi: Akdeniz Üniversitesi İletişim Fakültesi Öğrencilerine Yönelik Araştırma, Gümüşhane University, E-Journal of Faculty of Communication, 4 (1): 253-274.

Sutton, D. (2009) Globalizing Ideal Beauty: Women, Advertising, and the Power of Marketing. Springer.

Şimşek, S. (2006) Reklam ve Geleneksel Imgeler. İstanbul: Nüve Kültür Merkezi Yayınları

Tayfur, G. (2006) Reklamcılık. Ankara: Nobel Yayınları.

Topsümer, F.\& Elden, M. (1997) Reklamcıllk: Kavramlar, Kararlar, Kurumlar, İstanbul: İletişim Yayınları.

Tosun, N.B. (2014) Marka Yönetimi. İstanbul: Beta Yayınları.

Ünsal, Y. (1994) Bilimsel Reklam ve Pazarlamadaki Yeri. İstanbul: Tivi Reklam.

Vemuri, P. \& Madhav, K. (2004). Celebrity Endorsement: Through The Age. The Case Center.

Zahaf, M., \& Anderson, J. (2008) Causality Effects between Celebrity Endorsement and The Intentions To Buy. Innovative Marketing, 4(4): 57-65.

Zengin, G. (2018) Banka Reklamlarında Mizah ve Ünlü Kullanımı: Reklam Tutumlarına Yönelik Bir Araştırma. International Journal of Social Science, 65: 417-432. 